\title{
Formulating Strategies for Increasing Business Competitiveness Using Performance Prism, SWOT, and SOAR
}

\author{
Muhammad Fuad Arif ${ }^{1}$ andLukmandono ${ }^{2}$ \\ ${ }^{1,2}$ Faculty of Industrial Technology \\ InstitutTeknologi Adhi Tama Surabaya \\ arifdauffan@gmail.com
}

\begin{abstract}
RSI $X$ is a health care institution, which now facing a growing number of competitors in its vicinity ranging from general hospital, private health clinic, and local community health centers. Not to mention many smaller health clinics owned privately by doctors. This growing number of competitors, urge RSI X to assess its current performance and to determine its strategies to be able to compete and grow its market segment.

The purpose of this research is to assess RSI X current performance and to formulate appropriate business strategies in order to face the aforementioned competitors. The results of this research are performance measurement result using performance prism method and formulation of strategies using SWOT and SOAR methods. From 45 targets and 45 key performance indicators (KPI), 14 of them are good, 21 of them are moderate, and 10 of them are poor. Furthermore, from SWOT and SOAR analysis, 14 strategies are formulated.
\end{abstract}

Keywords: Performance Prism, SWOT, SOAR

\section{INTRODUCTION}

Business competition are getting fierce each day. Growing number of competitors, urge businesses to assess their current performance and devise better strategies in order to be competititve in their respective market and be profitable.

RumahSakit Islam (RSI) $\mathrm{X}$ is a health care institution, which now facing a growing number of competitors in its vicinity ranging from hospitals, health clinics, and local community health centers. This growing competition might threat RSI X current position, and if RSI X doesn't respond accordingly, they will no longer be competitive in their business. This condition urges RSI $X$ to reevaluate their current performance, so that they will be able to determine the best strategies in order to be competitive and grow their market segment in the future.

Performance measurement is an important measure in order for business to evaluate their business performance. Performance measurement is needed to analyze the difference that might arise from the achieved performance (actual performance obtained by current condition) with the objective performance (performance that was expected by the institution). This measurement is a starting point for improvement should businesses find their performance underperformed (Rai, 2008).

Performance prism method is a new method of performance measurement. This method is devised to improve previous performance measurement models. The model is not only based on the strategy but also pay attention to the satisfaction and contributions of stakeholders, processes and capabilities of the institution (Neely and Adam, 2000). By using the Performance Prism method it is expected that RSI X will formulized a proper objectives and performance indicators according to the need to achieve stakeholder satisfaction. Stakeholders' satisfaction is an important matter in order to establish a company that excels, and in turn, will make RSI X to be more competitive.

Once the performance measurement is done, then SWOT and SOAR analysis can be performed in order to devise new strategies. The purpose of this research is to assess RSI X current performance and devise new strategies in order to increase businesses' competitiveness.

\section{LITERATURE REVIEW}

\section{A. Competitiveness}

According Frinces (2011), competitiveness pertains to the ability and performance of a firm to create, sell, and supply goods and services in a 
given market, in relation to the ability and performance of other firms in the same market.Furthermore,Sumiharjo (2008) argued that high-performance firms exhibit the following abilities:

- Ability to strengthen its market share;

- Ability to connect with the environment;

- The ability to improve and sustain performance;

- The ability to keep or improve the firm's profitability.

\section{B. Performance Prism Method}

According to Neely AD Kennerley (2002), performance prism is a refinement of previously existed performance measuring technique. The advantage of this method is that it involves the use of framework which is consisted of all stakeholders of the firm including: investors, customers, end-users, employees, distributors, partners, communities, and regulators. This framework is illustrated in Figure 1.

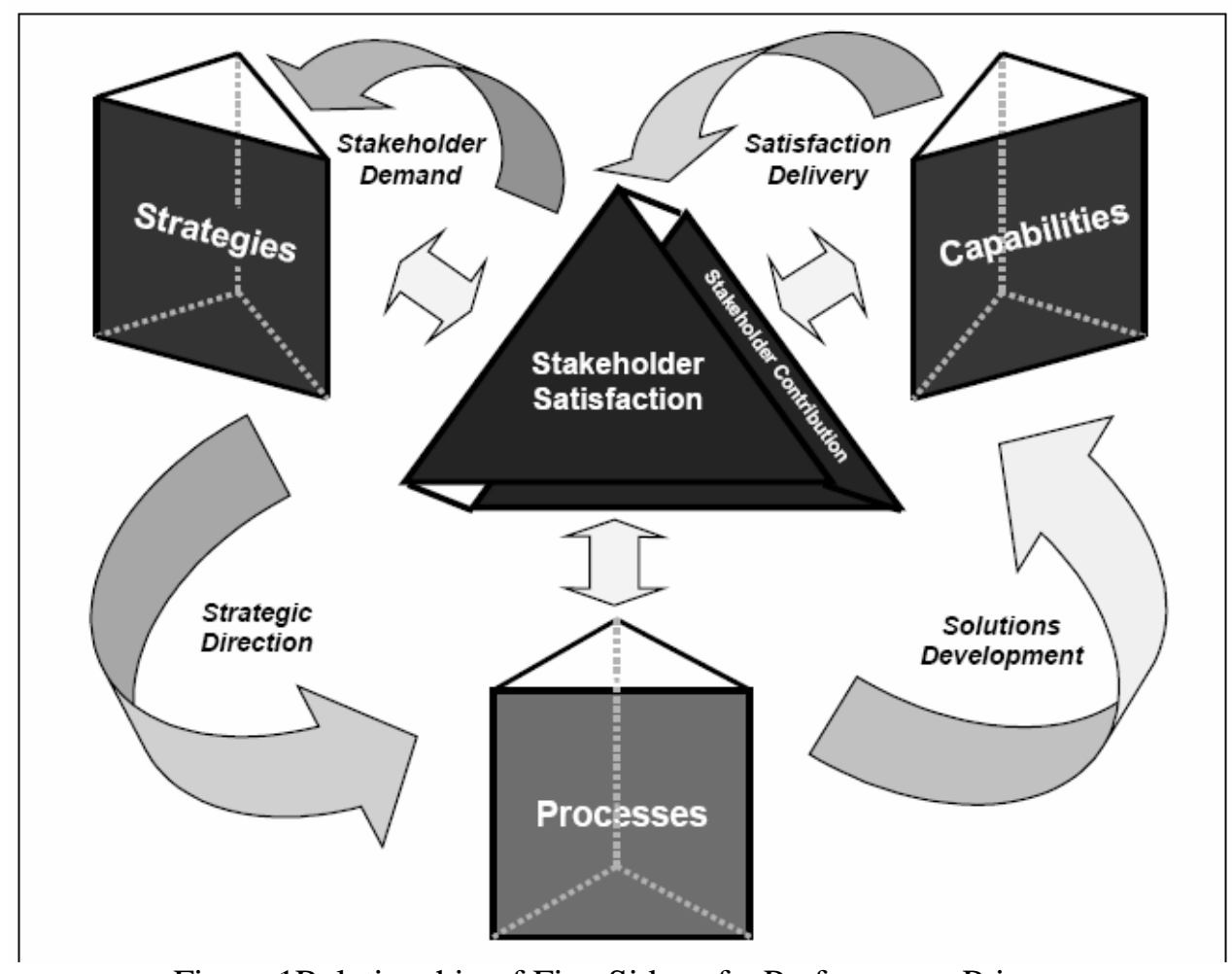

Figure 1Relationship of Five Sides of a Performance Prism

(Source: Neely A.D. Kennerley,2002)

\section{SWOT Method}

According to Lukmandono et al. (2019), SWOT analysis is a tool used for strategic planning in an organization. This tool can also be effectively used in building competitive strategies. Rangkuti (2009) explains that the SWOT matrix is a tool used to compile corporate strategy factors. This matrix can clearly illustrate how external opportunities and threats faced by companies are adjusted to their strengths and weaknesses.

\section{SOAR Method}

According to Stavros and Hinrichs (2009) SOAR (strengths, opportunities, aspirations, and results) is a strategic planning framework with an 16| TiBuana, Vol.3, No.1, 2020 approach that focuses on strengths and seeks to understand the whole system by including opinions of relevant stakeholders. This approach allows organizations to build a future through collaboration, mutual understanding, and commitment to action.

\section{RESEARCH METHOD}

The research method is divided into several stages. The first stage is the preparation stage: determining the object of research, preliminary studies including survey of research object and literature studies. The second stage is the stage of determining the method of data collection, types of data, and operational definitions of variables. 


\section{Tibuana}

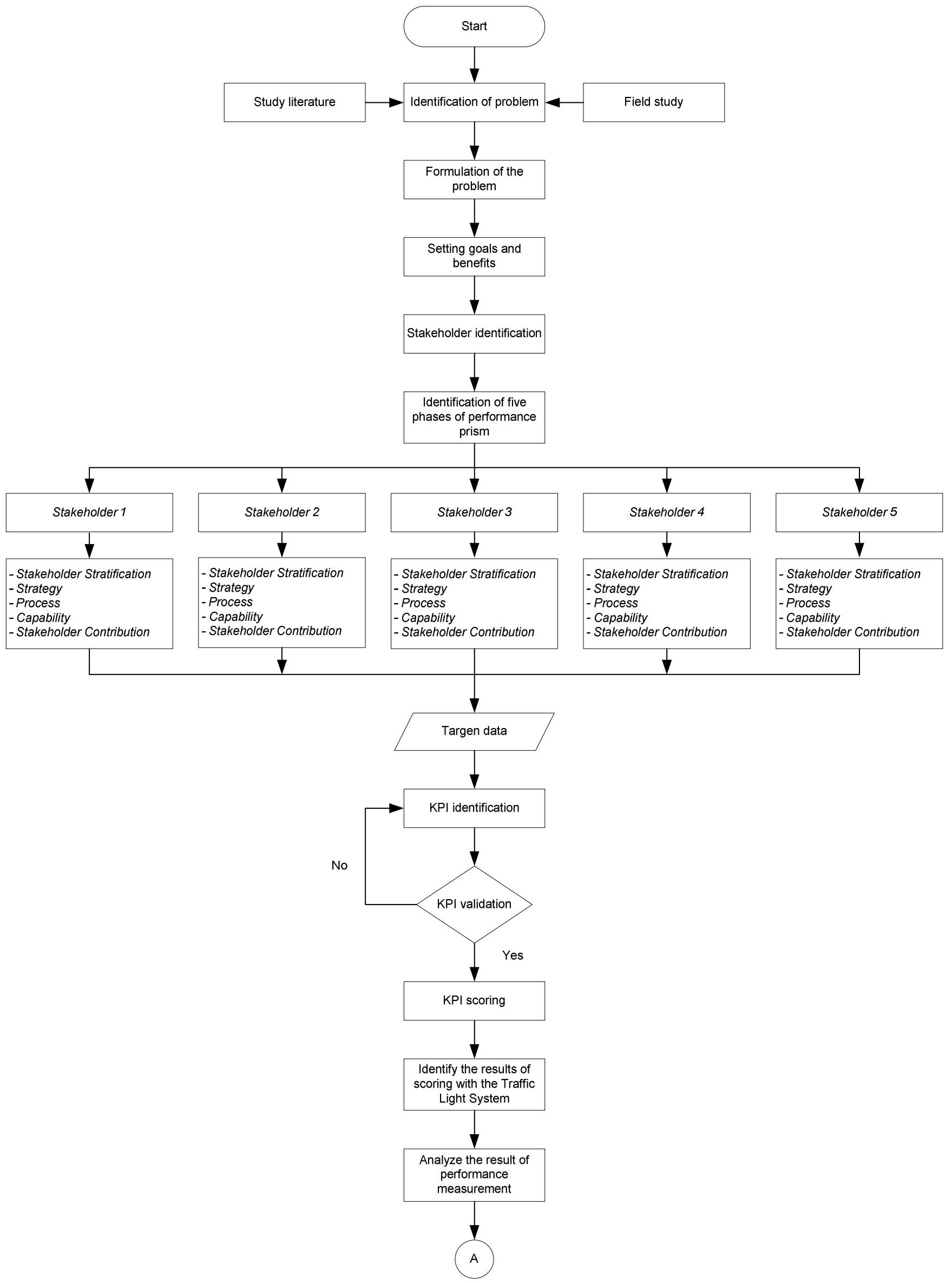




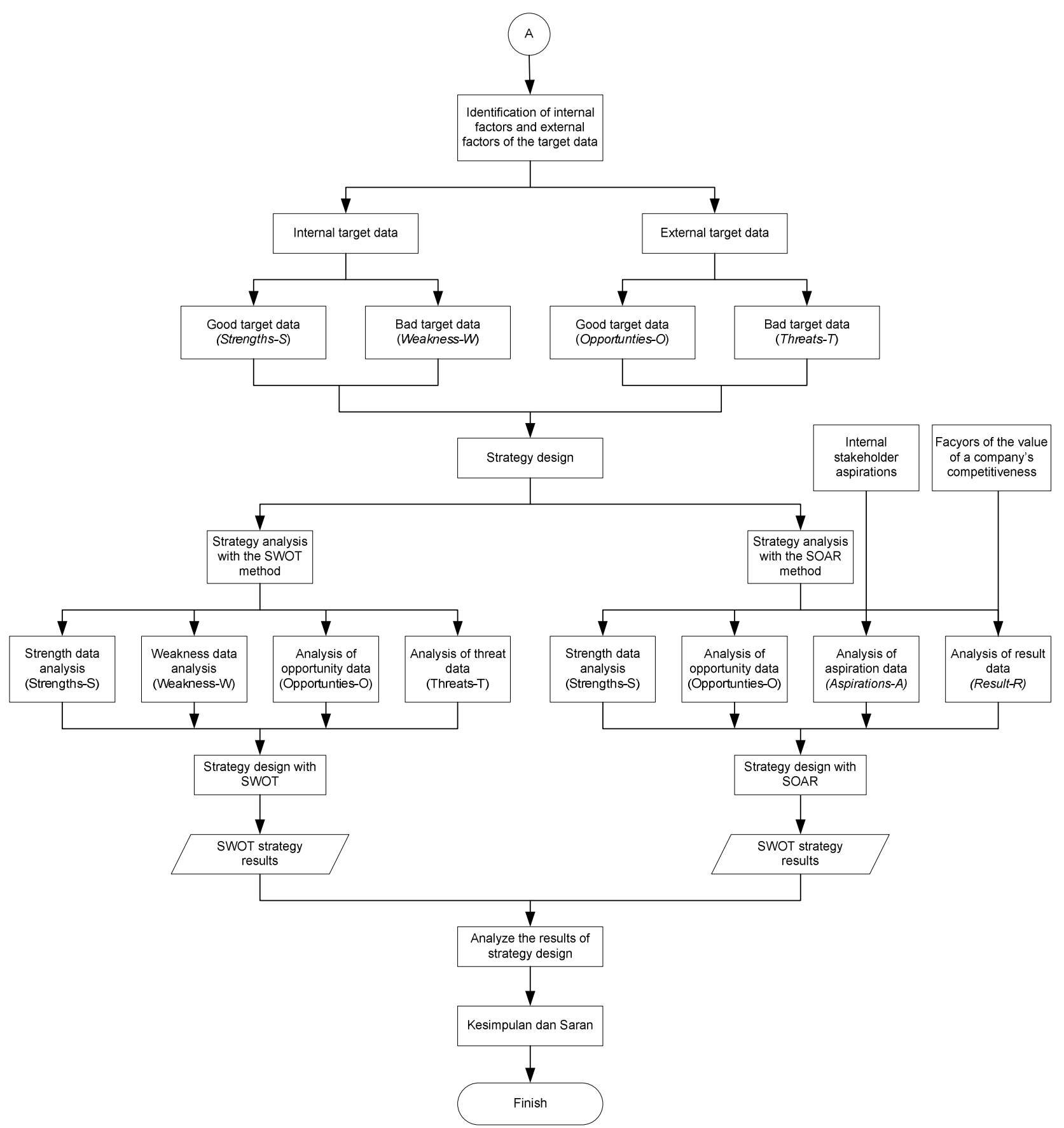

Figure 2. Research Methodology

The third stage is the stage of data collection and processing. In this stage there are several processes, the first process is to measure the performance of RSI X using the performance prism method, then to design a strategy with the SWOT and SOAR methods. The fourth stage is

\section{RESULTS AND DISCUSSIONS}
A. Performance
Measurement
using

Performance Prism Method

Identification of RSI X stakeholders needs to be carried out first before designing performance measurement. The following are RSI $X$ 18 | TiBuana, Vol.3, No.1, 2020 drawing conclusions and suggestions based on the aforementioned analysis. The research method used can be summarized as chart given in Figure 2.

stakeholders.

1. Consumers

Consumers are referred to the patients treated at the RSI X.

2. Employees 
Tibuana

Journal of applied Industrial Engineering-University of PGRI AdiBuana

Employees are referred to all employees who are currently listed as employee at RSI X.

3. Investors

Investorsare referred to all investors to RSI $\mathrm{X}$.

4. Suppliers

Suppliers are parties who supplies equipment needed for RSI X operations.

5. TheNahdlotul Ulama (NU) community

The Nahdlotul Ulama community is referred to member ofNahdlotul Ulama organization.

After identification of stakeholders, target factors are then compiled through the identification of five phases of performance prims for each stakeholder. The five phases of the performance prism perspective include: stakeholder stratification, strategy, process, capability, and stakeholder contribution. After setting targets, KPIs preparation is then carried out by validating KPIs to management. After validation, the KPI scorring stage and the traffic light system (TLS) are conducted. The scorringstage or assessment are then conducted using the formula:

Score $=$ Realization $/$ Target $\mathrm{x} 100 \%$ or

Score $=$ Target $/$ Realization $\times 100 \%$

depending on the type of KPIs, whether to maximize or minimize. As for the assessment using TLS, the author used the rating scale as can be seen in Table 1. The results of the RSI X performance measurement can be seen in Table 2.

Table 1. Rating Scale used for Assessment using TLS

\begin{tabular}{ccc}
\hline Score $(X)$ & Color & Ratings \\
\hline $\mathrm{X} \leq 50$ & Rating & Target is not achieved \\
$51 \leq \mathrm{X} \geq 79$ & Yellow & Target is not achieved \\
$80 \geq \mathrm{X}$ & Green & Target is not achieved \\
\hline
\end{tabular}

Table 2. Performance Measurement Result

\begin{tabular}{|c|c|c|c|c|c|}
\hline No. & Stakeholder & Perspective & KPI Code & Score & Traffic Light System \\
\hline \multirow{12}{*}{1} & \multirow{12}{*}{ Consumers } & \multirow{3}{*}{$\begin{array}{l}\text { Stakeholder } \\
\text { Satisfaction }\end{array}$} & SC 1 & 40 & \\
\hline & & & SC 2 & 70 & \\
\hline & & & SC 3 & 90 & \\
\hline & & \multirow{3}{*}{ Strategy } & $\mathrm{SC} 4$ & 20 & \\
\hline & & & SC 5 & 70 & \\
\hline & & & SC 6 & 90 & \\
\hline & & \multirow{3}{*}{ Process } & SC 7 & 65 & \\
\hline & & & SC 8 & 80 & \\
\hline & & & SC 9 & 90 & \\
\hline & & \multirow{2}{*}{ Capability } & SC 10 & 40 & \\
\hline & & & SC 11 & 85 & \\
\hline & & $\begin{array}{c}\text { Stakeholder } \\
\text { Contribution }\end{array}$ & SC 12 & 85 & \\
\hline \multirow{8}{*}{2} & \multirow{8}{*}{ Employees } & \multirow{2}{*}{$\begin{array}{l}\text { Stakeholder } \\
\text { Satisfaction }\end{array}$} & STK 1 & 70 & \\
\hline & & & STK 2 & 70 & \\
\hline & & \multirow{2}{*}{ Strategy } & STK 3 & 80 & \\
\hline & & & STK 4 & 60 & \\
\hline & & \multirow{2}{*}{ Process } & STK 5 & 50 & \\
\hline & & & STK 6 & 30 & \\
\hline & & Capability & STK 7 & 35 & \\
\hline & & Stakeholder & STK 8 & 70 & \\
\hline
\end{tabular}




\begin{tabular}{|c|c|c|c|c|}
\hline & & Contribution & STK 9 & 85 \\
\hline \multirow{10}{*}{3} & \multirow{10}{*}{ Investors } & \multirow{2}{*}{$\begin{array}{l}\text { Stakeholder } \\
\text { Satisfaction }\end{array}$} & SI 1 & 35 \\
\hline & & & SI 2 & 55 \\
\hline & & \multirow{2}{*}{ Strategy } & SI 3 & 60 \\
\hline & & & SI 4 & 50 \\
\hline & & \multirow{2}{*}{ Process } & SI 5 & 50 \\
\hline & & & SI 6 & 65 \\
\hline & & \multirow{2}{*}{ Capability } & SI 7 & 40 \\
\hline & & & SI 8 & 60 \\
\hline & & \multirow{2}{*}{$\begin{array}{l}\text { Stakeholder } \\
\text { Contribution }\end{array}$} & SI 9 & 60 \\
\hline & & & SI 10 & 75 \\
\hline \multirow{5}{*}{4} & \multirow{5}{*}{ Suppliers } & $\begin{array}{l}\text { Stakeholder } \\
\text { Satisfaction }\end{array}$ & SS 1 & 85 \\
\hline & & Strategy & SS 2 & 80 \\
\hline & & Process & SS 3 & 90 \\
\hline & & Capability & SS 4 & 90 \\
\hline & & $\begin{array}{l}\text { Stakeholder } \\
\text { Contribution }\end{array}$ & SS 5 & 80 \\
\hline \multirow{9}{*}{5} & \multirow{9}{*}{$\begin{array}{l}\text { The Nahdlotul Ulama } \\
\text { (NU) community }\end{array}$} & \multirow{2}{*}{$\begin{array}{l}\text { Stakeholder } \\
\text { Satisfaction }\end{array}$} & SPK 1 & 95 \\
\hline & & & SPK 2 & 85 \\
\hline & & \multirow{2}{*}{ Strategy } & SPK 3 & 83.3333 \\
\hline & & & SPK 4 & 75 \\
\hline & & \multirow{2}{*}{ Process } & SPK 5 & 100 \\
\hline & & & SPK 6 & 40 \\
\hline & & Capability & SPK 7 & 35 \\
\hline & & \multirow{2}{*}{$\begin{array}{l}\text { Stakeholder } \\
\text { Contribution }\end{array}$} & SPK 8 & 85 \\
\hline & & & SPK 9 & 90 \\
\hline
\end{tabular}

Source: data processing

From the above result, it can be seen that there are $14 \mathrm{KPIs}$ that have good values, $21 \mathrm{KPIs}$ have moderate values, while $10 \mathrm{KPIs}$ have poor values.

\section{B. Strategy formulation}

Strategy formulation is carried out by using 2 methods, namely SWOT and SOAR methods. Strategy development using SWOT takes into account both internal and external factors. Internal target data that has good value will be used as data to form strength factors and internal target data that has bad value will be used as data to form a weakness factor. Furthermore, for external target data that has good value will be used as data to form opportunities factors and external target data that has bad value will be used as data to form threats factors.

After the requireddata has been obtained, strategy is then formulated using the SWOT matrix. The results of the strategy formulation can be seen in Table 3 . 


\section{Tibuana}

Journal of applied Industrial Engineering-University of PGRI AdiBuana

Table 3. Strategy Formulation using SWOT

\begin{tabular}{|c|c|c|}
\hline $\begin{array}{l}\text { EksternalFactors } \\
\text { (EFAS) }\end{array}$ & \begin{tabular}{|l}
\multicolumn{1}{c}{ Strengths $(\mathbf{S})$} \\
List of internal strength factor: \\
$-\quad$ Good service quality \\
$-\quad$ Good employees' loyalty \\
- Good relation with suppliers \\
$-\quad$ Good relation with partners \\
$-\quad$ Has policies that encourage \\
research and internship program \\
$-\quad$ Very popular among students \\
and researchers alike for doing \\
research and internship
\end{tabular} & $\begin{array}{l}\text { Weakness }(\mathbf{W}) \\
\text { List of internal weakness factors: } \\
-\quad \text { Peningkatan dan perbaikansarpras } \\
\text { yang lambat } \\
-\quad \text { Lacking in facility and its } \\
\text { improvement } \\
\text { - Lacking in employees' training } \\
\text { program } \\
-\quad \text { Poor employees' welfare } \\
-\quad \text { No sustainable increase in } \\
\text { employees' wages } \\
-\quad \text { Lacking of funds for management } \\
\text { and facility improvement and } \\
\text { social activities } \\
\end{array}$ \\
\hline 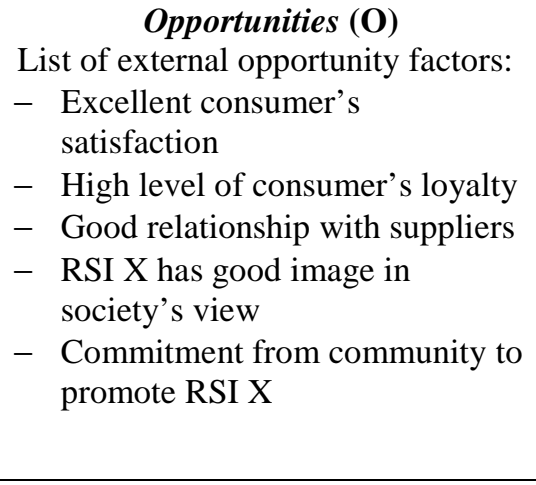 & \begin{tabular}{l}
\multicolumn{1}{c}{ Strategies (S-O) } \\
Strategies that utilize strength in \\
order to take advantage of \\
available opportunities: \\
1. Provide a place of research and \\
internship for researcher and \\
student on continuous basis \\
2. Strengthen promotion through \\
the Nahdlatul Ulama \\
community \\
3. Strengthen promotion by \\
utilizing loyal consumers
\end{tabular} & \begin{tabular}{l}
\multicolumn{1}{c}{ Strategies (W-O) } \\
Strategies that aim to minimize \\
weaknesses: \\
- Increase the amount of funds to \\
improve supporting facilities \\
$-\quad$ Hire more and better human \\
resources especially doctors
\end{tabular} \\
\hline $\begin{array}{l}\text { Threats (T) } \\
\text { List of external threat factors: } \\
-\quad \text { RSI is considered lacking } \\
\text { supporting facilities by } \\
\text { consumers }\end{array}$ & \begin{tabular}{l}
\multicolumn{1}{c}{ Strategies (S-T) } \\
Strategies that utilize strength to \\
overcome threats: \\
4. Promote RSI X as health care \\
institution with excellent quality \\
of service \\
5. Establish more cooperation with \\
educational institution
\end{tabular} & \begin{tabular}{l}
\multicolumn{1}{c}{ Strategies (W-T) } \\
Strategiesthat minimize weaknesses \\
and avoid possible threats: \\
- Strengthening RSI X promotion \\
through media as primary health \\
care services with excellent \\
service quality at affodable price
\end{tabular} \\
\hline
\end{tabular}

Source: data processing

Strategy formulation using SWOT analysis obtained 8 strategies. Next step in strategy formulation is to perform SOAR analysis to complete the strategy formulation for RSI X. In formulating strategies using SOAR analysis, it requires data on strengths, opportunities, aspirations, and results.

Data on strength and opportunities of RSI X were obtained from the analysis of internal factors and external factors that have been done before. Then the aspiration factor data is obtained from the distribution of open questionnaires to all RSI X employees and the result factor data is the data obtained from the translation of opportunities and aspirations. Furthermore, the result factor data is obtained from the translation of the company's competitiveness capabilities proposed by Sumiharjo (2008). Strategy formulation using SOAR analysiscan be seen in Table 4. 
Table 4. PenyusunanStrategidenganSOAR

\begin{tabular}{|c|c|c|}
\hline SOAR MATRIX & $\begin{array}{l}\text { Strengths }(\mathbf{S}) \\
\text { List of internal strength factor: } \\
\text { - Good service quality } \\
- \text { Good employees' loyalty } \\
- \text { Good relation with suppliers } \\
- \text { Good relation with partners } \\
-\quad \text { Has policies that encourage } \\
\text { research and internship } \\
\text { program } \\
-\quad \text { Very popular among } \\
\text { students and researchers } \\
\text { alike for doing research and } \\
\text { internship }\end{array}$ & \begin{tabular}{l}
\multicolumn{1}{c}{ Opportunities $(\mathbf{O})$} \\
List of external opportunity \\
factors: \\
$-\quad$ Excellent consumer's \\
satisfaction \\
$-\quad$ High level of consumer's \\
loyalty \\
$-\quad$ Good relationship with \\
suppliers \\
$-\quad$ RSI X has good image in \\
society's view \\
$-\quad$ Commitment from \\
community to promote RSI X
\end{tabular} \\
\hline $\begin{array}{l}\text { Aspirations (A) } \\
\text { List of aspirations: } \\
\text { - Employees' salaries can be raised in } \\
\text { accordance to municipality's } \\
\text { minimum wage policy } \\
\text { - } \text { RSI X becoming a more } \\
\text { comfortable working place } \\
\text { - Creating a better working culture } \\
\text { - } \text { Better supporting facilities } \\
\text { - } \text { RSI X must implement a valid } \\
\text { performance measurement in order } \\
\text { to achieve its target } \\
\text { - RSI X should employ a better } \\
\text { information system } \\
\text { - RSI X becoming the first choice for } \\
\text { patient especially those from the } \\
\text { Nahdlotul Ulama community } \\
\end{array}$ & $\begin{array}{l}\text { Strategies (S-A) } \\
\text { Strength-based strategies for } \\
\text { achieving measurable results: } \\
\text { - Implement OCAI work } \\
\text { culture, namely: clan } \\
\text { culture, adhocracy culture, } \\
\text { market culture, and } \\
\text { hierarchy culture } \\
\text { - Implement an integrated } \\
\text { information systems } \\
\text { - Promote RSI through } \\
\text { collaboration with } \\
\text { educational institutions as } \\
\text { the main place for health } \\
\text { services for the institution's } \\
\text { community. }\end{array}$ & $\begin{array}{l}\text { Strategies (O-A) } \\
\text { Aspiration-oriented strategies } \\
\text { that can be implemented to take } \\
\text { advantage of available } \\
\text { opportunities: } \\
\text { - Promote RSI through } \\
\text { collaboration with institutions } \\
\text { within NU community. }\end{array}$ \\
\hline $\begin{array}{l}\text { Results (R) } \\
\text { List of desired results: } \\
\text { - Ability to strengthen its market } \\
\text { share: } \\
\text { (RSI X becomes number } 1 \\
\text { choice to get health care services } \\
\text { for the nearby community) } \\
\text { - Ability to connect with the } \\
\text { environment: } \\
\text { (RSI X should strengthen } \\
\text { collaboration with various } \\
\text { educational institutions and } \\
\text { various companies) } \\
\text { - Maintaining continuous } \\
\text { improvement: } \\
\text { (providing quality service at a } \\
\text { standard cost) } \\
\text { - Established a favorable position: } \\
\text { (Establishing RSI X as the main } \\
\text { health care service especially for } \\
\text { NU community) }\end{array}$ & \begin{tabular}{l}
\multicolumn{1}{c}{ Strategies (S-R) } \\
Strength-based strategies for \\
creating measurable results: \\
- Provide quality health care \\
service at affordable costs \\
- Maintain continuous \\
collaboration with \\
educational institutions and \\
nearby companies.
\end{tabular} & $\begin{array}{l}\text { Strategies (O-R) } \\
\text { Strtegies that are oriented } \\
\text { towards opportunities to achieve } \\
\text { measurable results: } \\
\text { Strategi yang berorientasi } \\
\text { - } \text { RSI X promotes itself as a } \\
\text { health care institution formed } \\
\text { by the people of District A } \\
\text { and must become the pride } \\
\text { hospital of District A people } \\
\text { - Utilize xonsumer loyalty to } \\
\text { promote RSI X }\end{array}$ \\
\hline
\end{tabular}

Source: data processing 
The results of the strategy formulation using SOAR analysis obtained a total of 8 strategies. The strategy obtained from the results of the analysis is expected to be a consideration material for the institution to improve its performance, so that the company will be more competitive and maintain a positive business for the foreseeable future.

\section{CONCLUSION}

From this study it can be concluded that from the performance measurement of RSI X there are 14 KPIs that have good values, 21 KPIs have moderate values, while $10 \mathrm{KPIs}$ have poor values with a total of 45 KPIs. Then, the company strategy is formulated using the SWOT and SOAR methods. The results of the design of the strategy obtained 8 strategies from the SWOT method and 8 strategies from SOAR. If the strategy is adjusted, 14 strategies will be obtained. These strategies are:

1. Provide a place of research and internship for researcher and student on continuous basis.

2. Strengthen promotion through the Nahdlatul Ulama community.

3. Strengthen promotion by utilizing loyal consumers.

4. Increase the amount of funds to improve supporting facilities.

5. Hire more and better human resources especially doctors.

6. Promote RSI X as health care institution with excellent quality service.

7. Strengthening RSI X promotion through media as primary health care services with excellent service quality at affordable price.

8. Implement OCAI work culture, namely: clan culture, adhocracy culture, market culture, and hierarchy culture

9. Implementation integrated information systems.

10. Promote RSI through collaboration with educational institutions as the main place for health services for the institution's community.

11. Promote RSI through collaboration with institutions within NU community.

12. RSI $X$ promotes itself as a health care institution formed by the people of District A and must become the pride hospital of District A people.

13. Provide quality health care service at affordable costs.

14. Maintain continuous collaboration with educational institutions and nearby companies.

\section{REFERENCES}

1. Lukmandono, dkk. 2019. Determination of Digital Marketing Strategies by using SWOT and BCG Approaches to Improve Company Competitiveness. Seminar Internasional IECSE, Makasar.

2. Neely, A.D and C. A. Adams. 2000. The Performance prism Can Boost M \& A Success. Centre for Business Performance, Cranfield School of Management. UK: Prentice Hall.

3. Neely, A.D. Kennerley, $M$ and Adams, C.A. 2002. The Performance Prism. The Scorecard for Measuring and managing Business Success. UK: Prentice Hall.

4. Rai, I.G.A. 2008. Audit Kinerja pada Sektor Publik Konsep, Praktik, dan Studi Kasus. Jakarta: Salemba Empat

5. Stavros, J., \& Hinrichs, G. 2009. Thin book of SOAR: Building strengths-based strategy. Bend, OR: Thin Book Publishers.

6. Sumiharjo, Tumar. 2008. PenyelenggaraanPemerintah Daerah MelaluiPengembanganDayaSaingBerbasis Potensi Daerah. Bandung: Fokusmedia.

7. Rangkuti, Freddy. 2009. Analisis SWOT Teknik MembedahKasusBisnis. Jakarta: Penerbit PT GramediaPustaka Utama. 